\title{
Carbohydrate fermentation by gut microflora in preterm neonates
}

\author{
V WALKER, ${ }^{*}$ G A MILLS, ${ }^{*}$ M A HALL, $\dagger$ AND J A LOWES $\ddagger$ \\ Departments of *Clinical Biochemistry and †Child Health, Southampton University, and $\ddagger P u b l i c$ Health \\ Laboratory Service, Southampton General Hospital
}

SUMmARY To study organic acid excretion, urine was collected from 52 preterm infants at weekly intervals and analysed by capillary gas chromatography-mass spectrometry. Twelve of 22 babies born before 33 weeks' gestation excreted 2,3-butanediol, as did six born between 33 and 36 weeks. Six very immature babies also excreted acetoin, the metabolic precursor of the diol. Other products derived from carbohydrate included methylmalonic and ethylmalonic acids in one baby, and D-lactic acid in five. Acetoin has never been found in urine before, and the other four acids have been found only rarely. Excretion of these metabolites by preterm babies can be explained by increased intestinal permeability, unabsorbed lactose in the colon, and colonisation with certain opportunistic micro-organisms prevalent in neonatal units, including klebsiella, serratia, and enterobacter. The findings support evidence from breath hydrogen analysis that carbohydrate fermentation takes place in the gut of preterm infants.

The colonic microflora can ferment carbohydrates, producing a range of organic acids ${ }^{1}$ that may be absorbed from the intestine. ${ }^{2}$ Some undergo further metabolism by the host $^{34}$ and may provide an important source of energy, ${ }^{2}$ particularly for premature babies. ${ }^{56}$ These acids cannot normally be detected in urine by conventional gas chromatography techniques. Certain carbohydrate fermentation products may become detectable in rare circumstances, however, when the gut physiology is disturbed. For example, D-lactic acid excretion has been reported in preterm babies with necrotising enterocolitis, ${ }^{7}$ and in older subjects following extensive ileal resection when large amounts of unabsorbed carbohydrate in the colon were metabolised by lactobacilli. $^{89}$ Transient methylmalonic aciduria in a child with Hirchsprung's disease was attributed to gut bacterial activity. ${ }^{10}$ Finally, two acidotic babies without an inherited metabolic defect were found to excrete 2,3-butanediol, an abnormal metabolite that was probably also derived from bacterial metabolism. ${ }^{11}$

A study was undertaken to investigate the organic acid excretion of premature babies. An unexpected finding was that products of bacterial carbohydrate fermentation were frequently detected in samples from babies born before 33 weeks' gestation.

\section{Patients and methods}

Fifty two preterm babies admitted to the special care baby unit of the Princess Anne Hospital, Southampton, from June to November 1985 were studied during their normal clinical management for up to 83 days of life. For the purpose of analysis, study patients were divided into two groups: 22

Table 1 Details of infants studied

\begin{tabular}{lcc}
\hline & $\begin{array}{l}\text { Group 1 } \\
\text { (<33 weeks' } \\
\text { gestation) }\end{array}$ & $\begin{array}{l}\text { Group 2 } \\
(33-36 \text { weeks } \\
\text { gestation) }\end{array}$ \\
\hline $\begin{array}{l}\text { No of babies } \\
\text { Median (range) } \\
\text { gestation (weeks) }\end{array}$ & 22 & 30 \\
$\begin{array}{l}\text { Median (range) } \\
\text { birth weight (g) } \\
\begin{array}{c}\text { Median (range) } \\
\text { No of days monitored }\end{array}\end{array}$ & $28(25-32)$ & $34(33-36)$ \\
$\begin{array}{l}\text { Total No of urine } \\
\text { samples taken }\end{array}$ & $1160(730-1950)$ & $2155(1400-2670)$ \\
$\begin{array}{c}\text { No of samples taken } \\
\text { after age 7 days }\end{array}$ & 109 & $17(0-29)$ \\
$\begin{array}{l}\text { Mean (range) creatinine } \\
\text { concentration (mmol/1) } \\
\text { after age } 7 \text { days }\end{array}$ & $1 \cdot 12(0 \cdot 15-3 \cdot 60)$ & $1 \cdot 01(0 \cdot 10-2 \cdot 23)$ \\
\hline
\end{tabular}


babies born before 33 weeks' gestation (group 1), and 30 born between 33 and 36 weeks' gestation (group 2) (table 1). Nineteen babies in group 1 $(86 \%)$ and two in group $2(7 \%)$ were of very low birth weight (VLBW: birth weight less than $1500 \mathrm{~g}$ ), and five babies in group 1 weighed less than $1000 \mathrm{~g}$. Two babies in group 1, and 11 in group 2, were classed as small for gestational age, having a birth weight below the 10th centile for gestation.

Random urine samples were collected into a bag, once during the first $\mathbf{4 8}$ hours of life and then at weekly intervals until discharge. Samples were frozen immediately and stored at $-20^{\circ} \mathrm{C}$ without preservative.

For the first 72 hours the babies born before 33 weeks' gestation received dextrose intravenously. They were then fed parenterally until early respiratory and circulatory problems were overcome (generally up to 10-20 days of age). The full regimen was established over five days and comprised Vamin 9 glucose, $10 \%$ Intralipid, Ped-el, Vitlipid, and Solivito (all KabiVitrum), and 10\% dextrose. Oral feeding with expressed breast milk was introduced as the condition improved. Other milks were often substituted later and sometimes included a low birth weight formula (LBW Gold Cap SMA, Wyeth). Daily supplements of iron, l $\alpha$-cholecalciferol, and vitamins (Dalivit, Paines, and Byrne) were introduced from around 21 days. Parenteral nutrition was reintroduced if necrotising enterocolitis developed. The carbohydrate present in human milk and the standard formula feeds used was lactose, 12.6 to $13.1 \mathrm{~g}$ being provided by a daily intake of 180 $\mathrm{ml} / \mathrm{kg}{ }^{12}$ Low birth weight formula (SMA) contains lactose and maltodextrin $(1: 1), 180 \mathrm{ml} / \mathrm{kg}$ daily providing $7.74 \mathrm{~g}$ of each sugar. Babies of 33 to 36 weeks' gestation sometimes required dextrose intravenously in the first days of life, but were then fed orally on breast milk or formula feeds. Low birth weight formula (SMA) was given infrequently. None received parenteral nutrition.
Chemicals for analysis were obtained from either Sigma or Aldrich. Urine samples were tested for phenylketones, reducing substances and other abnormalities using Phenistix, Clinitest and Multistix, respectively, all from Ames, Miles Laboratories. Creatinine was measured by an alkaline picrate method. After oximation with hydroxylamine hydrochloride, urinary organic acids were extracted with ethyl acetate and diethyl ether, derivatised, and analysed by capillary gas chromatography. Unknown compounds were identified by combined gas chromatography-mass spectrometry. ${ }^{13}$ To enable comparisons, acids were quantified from their peak areas using n-tetracosane as internal standard and the concentrations related to urinary creatinine. Babies within each study group were of similar gestational age, chronological age, and birth weight, and after 7 days of life their urinary creatinine concentrations fell within a narrow range (table 1). Errors from the use of creatinine ratios are unlikely to have influenced the findings significantly. D-lactic acid was analysed kinetically by its conversion to pyruvate by D-lactate dehydrogenase (from Leuconostoc mesenteroides, Sigma) by a method based on that of Gawehn and Bergmeyer. ${ }^{14}$

Limited information about the faecal coliform organisms was available retrospectively for seven babies who were also recruited into a microbiological study. Rectal swabs were cultured aerobically on blood agar and MacConkey's medium. Coliform bacteria were identified using a commercial system (Mast Diagnostics). No attempt was made to isolate anaerobes.

The $\chi^{2}$ test was used to assess the significance of differences between groups. The study was approved by the local district ethics committee.

\section{Results}

URINARY EXCRETION OF 2,3-BUTANEDIOL AND ACETOIN Three unknown peaks were seen in the organic acid

Table 2 Metabolites derived from carbohydrates by bacteria detected in 216 urine samples

\begin{tabular}{|c|c|c|c|}
\hline Metabolite & $\begin{array}{l}\text { No of babies } \\
\text { who excreted } \\
\text { metabolite }\end{array}$ & $\begin{array}{l}\text { No }(\%) \\
\text { positive samples }\end{array}$ & $\begin{array}{l}\text { Median (range) metabolite } \\
\text { concentration ( } \mathrm{mg} / \mathrm{mmol} \text { creatinine) }\end{array}$ \\
\hline \multicolumn{4}{|c|}{ Gestational age $<33$ weeks ( 127 samples from 22 babies): } \\
\hline 2,3-Butanediol & 12 & $36(28)$ & $17.4(0.8-378 \cdot 4)$ \\
\hline Acetoin & 6 & $18(14)$ & 3.6 (trace-18.6) \\
\hline Methylmalonic acid & 1 & 4 (3) & $4 \cdot 6(4 \cdot 1-10 \cdot 8)$ \\
\hline \multicolumn{4}{|c|}{ Gestational age $33-36$ weeks ( 89 samples from 30 babies): } \\
\hline 2,3-Butanediol & 6 & $10(11)$ & $3 \cdot 6(0 \cdot 6-17 \cdot 0)$ \\
\hline Acetoin & 0 & 0 & \\
\hline Methylmalonic acid & 0 & 0 & \\
\hline Ethylmalonic acid & 0 & 0 & \\
\hline
\end{tabular}


profiles of some samples. Two of these were found to be isomers of the sugar metabolite 2,3-butanediol. The third peak was usually seen when large amounts of diol were present and was shown to be its metabolic precursor, acetoin. ${ }^{13}$ Acetoin was never seen in the absence of 2,3-butanediol. Neither compound was present in any of the milks, vitamins, or intravenous preparations given.

2,3-Butanediol was present in 46 of the total of 216 samples $(21 \%)$ (table 2$)$. The mesoisomer predominated, and in 21 samples was the only form present. More babies born before 33 weeks excreted the diol $(12$ of $22,55 \%)$ than those of 33 to 36 weeks' gestation (six of $30,20 \% ; \mathrm{p}<0.01$ ), and acetoin excretion was confined to this group. The concentrations of 2,3-butanediol detected were also higher, exceeding $10 \mathrm{mg} / \mathrm{mmol}$ creatinine in seven very immature babies $(31,32,71,139,224,351$, and $378 \mathrm{mg} / \mathrm{mmol}$ creatinine) compared with only two in the 33-36 week group (15 and $17 \mathrm{mg} / \mathrm{mmol}$ creati-

Table 3 Excretion of bacterial metabolites related to feeding and antibiotic treatment

\begin{tabular}{|c|c|c|c|c|c|c|c|c|}
\hline \multirow{2}{*}{$\begin{array}{l}\text { Case } \\
\text { No }\end{array}$} & \multirow{2}{*}{$\begin{array}{l}\text { Gestation } \\
\text { (weeks) }\end{array}$} & \multirow{2}{*}{$\begin{array}{l}\text { Birth } \\
\text { weight } \\
\text { (g) }\end{array}$} & \multirow{2}{*}{$\begin{array}{l}\text { No of } \\
\text { positive } \\
\text { samples }\end{array}$} & \multicolumn{4}{|c|}{ At time abnormality diagnosed } & \multirow{2}{*}{$\begin{array}{l}\text { Antibiotics given } \\
\text { before abnormality } \\
\text { diagnosed }\end{array}$} \\
\hline & & & & $\begin{array}{l}\text { Age } \\
\text { (days) }\end{array}$ & $\begin{array}{l}\text { Feed being } \\
\text { given }\end{array}$ & $\begin{array}{l}\text { Days on } \\
\text { oral feeds }\end{array}$ & $\begin{array}{l}\text { Days off } \\
\text { antibiotics }\end{array}$ & \\
\hline \multicolumn{9}{|c|}{ 2,3-Butanediol with or without acetoin: } \\
\hline 1 & 25 & 800 & 1 & 13 & $\begin{array}{l}\text { Total parenteral } \\
\text { nutrition, plus } \\
\text { expressed breast milk } \\
\text { for } 24 \text { hours }\end{array}$ & 1 & 0 & $\begin{array}{l}\text { Benzylpenicillin, cefotaxime; } \\
\text { in progress: gentamicin } \\
\text { and flucloxacillin }\end{array}$ \\
\hline 2 & 26 & 940 & 6 & $25-57$ & Expressed breast milk & 6 & 6 & $\begin{array}{l}\text { Benzylpenicillin, cefotaxime, } \\
\text { and flucloxacillin, amikacin, } \\
\text { and fucidin }\end{array}$ \\
\hline 3 & 26 & 862 & 4 & $30-64$ & Expressed breast milk & 10 & 18 & Benzylpenicillin and cefotaxime \\
\hline 4 & 26 & 900 & 5 & $38-67$ & Expressed breast milk & 23 & 13 & $\begin{array}{l}\text { Benzylpenicillin, cefotaxime } \\
\text { and flucloxacillin, gentamicin, } \\
\text { fucidin, and amikacin }\end{array}$ \\
\hline 5 & 28 & 1120 & 8 & $26-71$ & Expressed breast milk & 14 & 20 & Benzylpenicillin and cefotaxime \\
\hline 6 & 28 & 1220 & 1 & 37 & Formula feed (SMA) & 27 & 15 & $\begin{array}{l}\text { Benzylpenicillin, cefotaxime, } \\
\text { flucloxacillin, and gentamicin }\end{array}$ \\
\hline 8 & 28 & 1160 & 1 & 21 & Formula feed (SMA) & 10 & 11 & Benzylpenicillin and cefotaxime \\
\hline 9 & 29 & 1160 & 4 & 1443 & $\begin{array}{l}\text { Total parenteral } \\
\text { nutrition. plus } \\
\text { expressed breast milk } \\
\text { for } 24 \text { hours }\end{array}$ & $!$ & 0 & $\begin{array}{l}\text { Benzylpenicillin and cefotaxime: } \\
\text { in progress: flucloxacillin } \\
\text { and gentamic in gentamicin }\end{array}$ \\
\hline 10 & 30 & 1610 & 1 & 29 & Expressed breast milk & 10 & 4 & $\begin{array}{l}\text { Benzylpenicillin, cefotaxime, } \\
\text { azlocillin, and gentamicin }\end{array}$ \\
\hline \multirow[t]{2}{*}{11} & 31 & $1170^{*}$ & 2 & 29 and & Expressed breast milk & 20 & 20 & Benzylpenicillin and cefotaxime \\
\hline & & & & 53 & Expressed breast milk & 44 & 44 & Benzylpenicillin and cefotaxime \\
\hline 12 & 31 & 1860 & 2 & $15-22$ & $\begin{array}{l}\text { Total parenteral } \\
\text { nutrition and expressed } \\
\text { breast milk }\end{array}$ & 5 & 7 & Benzylpenicillin and cefotaxime \\
\hline 13 & 34 & $1760^{*}$ & 1 & 21 & Formula feed (Osterfeed) & 21 & 21 & None \\
\hline 14 & 34 & 2370 & 2 & $6-14$ & $\begin{array}{l}\text { Formula feed (SMA) } \\
\text { and dextrose }\end{array}$ & 6 & 3 & Benzylpenicillin and cefotaxime \\
\hline 15 & 34 & $1400^{*}$ & 2 & $10-12$ & $\begin{array}{l}\text { Low birth weight } \\
\text { formula feed (SMA) }\end{array}$ & 10 & 10 & None \\
\hline 16 & 34 & 2330 & 1 & 8 & Formula feed (SMA) & 8 & 5 & Benzylpenicillin and cefotaxime \\
\hline 18 & 34 & $1420^{*}$ & 2 & $23-29$ & Formula feed (SMA) & 23 & 23 & None \\
\hline \multicolumn{9}{|c|}{ Methylmalonic acid } \\
\hline 4 & 26 & 900 & 4 & $38-67$ & Expressed breast milk & 23 & 13 & $\begin{array}{l}\text { Benzylpenicillin, cefotaxime, } \\
\text { flucloxacillin, gentamicin, } \\
\text { fucidin, and amikacin }\end{array}$ \\
\hline \multicolumn{9}{|r|}{ 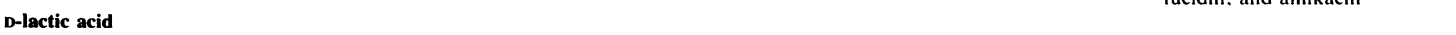 } \\
\hline 2 & 26 & 940 & 1 & 28 & Expressed breast milk & 9 & 9 & $\begin{array}{l}\text { Benzylpenicillin. cefotaxime, } \\
\text { flucloxacillin. gentamicin. } \\
\text { fucidin, and amikacin }\end{array}$ \\
\hline 3 & 26 & 862 & 1 & 30 & Expressed breast milk & 10 & 18 & Benzylpenicillin and cefotaxime \\
\hline+4 & 26 & 900 & 1 & 38 & Expressed breast milk & 23 & 13 & $\begin{array}{l}\text { Benzylpenicillin, cefotaxime, } \\
\text { flucloxacillin, gentamicin, } \\
\text { and fucidin }\end{array}$ \\
\hline 5 & 28 & 1120 & 2 & $43-51$ & Expressed breast milk & 29 & 35 & Benzylpenicillin and cefotaxime \\
\hline 9 & 29 & 1160 & 1 & 22 & Expressed breast milk & 3 & 2 & $\begin{array}{l}\text { Benzylpenicillin, cefotaxime, } \\
\text { flucloxacillin and gentamicin }\end{array}$ \\
\hline
\end{tabular}

*Birth weight less than 10 th centile for gestation: tinsufficient urine to confirm acid present. 
nine). Significantly more VLBW babies (12 of 21, $57 \%$ ) excreted the diol than babies born weighing more than $1500 \mathrm{~g}$ ( $\operatorname{six}$ of $31,19 \%, \mathrm{p}<0.01$ ), and four of the five babies weighing less than $1000 \mathrm{~g}$ at birth were diol excretors. The fifth infant had necrotising enterocolitis and received parenteral nutrition and intravenous antibiotics throughout the monitoring period. Four of $13(31 \%)$ babies born small for gestational age excreted the diol. This was similar to the incidence for babies of appropriate weight for gestational age (14 of $39,36 \% ; p>0.05)$.

\section{URINARY EXCRETION OF OTHER CARBOHYDRATE METABOLITES}

Methylmalonic acid was detected in four samples collected from one baby (gestational age 26 weeks) between 38 and 67 days of life. On three occasions small amounts of ethylmalonic acid were also found. High concentrations of lactic acid $(37,56$, and 102 $\mathrm{mg} / \mathrm{mmol}$ creatinine), respectively were present in three urine samples from two babies born before 33 weeks who were not acidotic, and there were moderately increased concentrations in three others. 2,3-Butanediol was also present in four of these samples, and it was suspected that they might

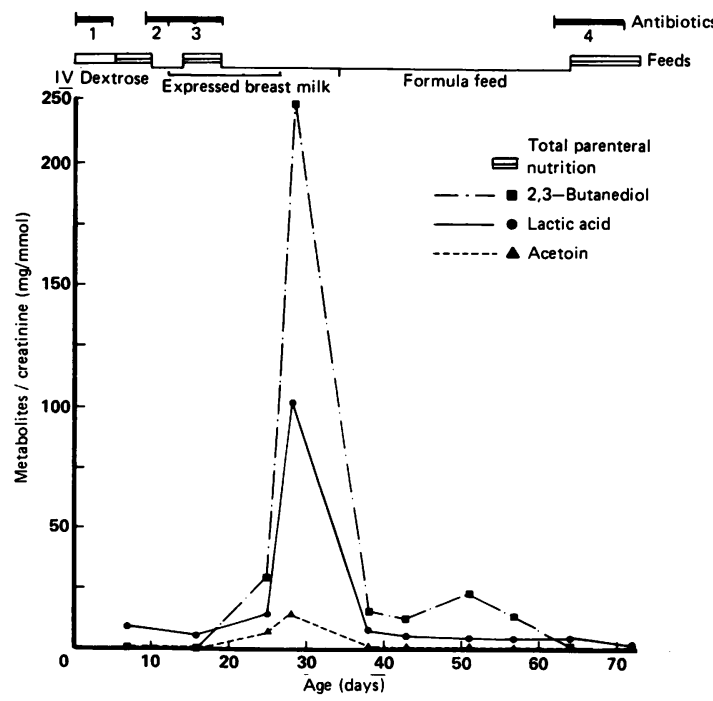

Fig 1 Excretion of bacterial carbohydrate metabolites by case 2, born at 26 weeks' gestation, birth weight $940 \mathrm{~g}$. She required artificial ventilation for 28 days. Necrotising enterocolitis developed at 60 days. Intravenous antibiotic treatment-1: Benzylpenicillin and cefotaxime.

2: Flucloxacillin, gentamicin, and fucidin. 3: Amikacin and fucidin. 4: Flagyl, ampicillin, and gentamicin.

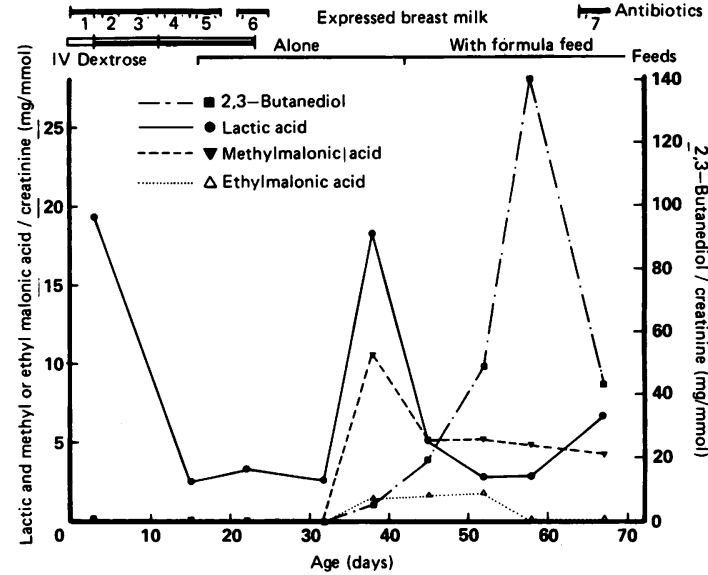

Fig 2 Excretion of bacterial carbohydrate metabolites by case 4, born at 26 weeks' gestation, birth weight $900 \mathrm{~g}$. She required artificial ventilation for 31 days. Necrotising entercolitis developed at 73 days. Intravenous antibiotic treatment-1: Benzylpenicillin and cefotaxime.

2: Benzylpenicillin, flucloxacillin, cefotaxime, and gentamicin. 3: Fucidin, amikacin and flucloxacillin. 4: Flucloxacillin and cefotaxime. 5: Benzylpenicillin and cefotaxime. 6: Flucloxacillin and cefotaxime. 7: Netilmicin and cefotaxime.

contain bacterially produced $\mathrm{D}$-lactic acid in addition to endogenous L-lactic acid. These isomers are not separated by our normal chromatographic procedure. Five of the samples were analysed using an enzyme method, ${ }^{14}$ and D-lactic acid was confirmed. This acid may also have been present at lower concentration in other samples, but it was not feasible to reanalyse all the specimens.

EXCRETION OF METABOLITES RELATED TO FEEDING, ANTIBIOTIC TREATMENT, AND MICROBIOLOGY OF RECTAL SWABS

Excretion of the abnormal carbohydrate metabolites was not a constant feature; only one episode coincided with the onset of proved or suspected necrotising enterocolitis, and this was in a baby who had been excreting 2,3-butanediol for at least 14 days. Table 3 summarises preceding antibiotic treatment, and the type of feeding being given when the urinary abnormality was first noticed. All the babies who excreted the metabolites were being fed orally. The products were not present in any of the 16 samples collected from 14 babies during total parenteral nutrition. Fourteen of these 16 collections were during courses of antibiotic treatment. In most cases, feeds were well established (five to $\mathbf{4 0}$ days). Two babies receiving parenteral nutrition, however, 
Table 4 Coliform micro-organisms grown from rectal swabs from three babies who excreted 2,3-butanediol

\begin{tabular}{|c|c|c|c|c|c|}
\hline $\begin{array}{l}\text { Case } \\
\text { No }\end{array}$ & $\begin{array}{l}\text { Gestation } \\
\text { (weeks) }\end{array}$ & $\begin{array}{l}\text { Chronological } \\
\text { age (days) }\end{array}$ & $\begin{array}{l}\text { Urinary 2,3-butanediol } \\
\text { ( } \mathrm{mg} / \mathrm{mmol} \text { creatinine) }\end{array}$ & Faecal bacteria & $\begin{array}{l}\text { Sensitive to } \\
\text { cefotaxime }\end{array}$ \\
\hline \multirow[t]{5}{*}{2} & \multirow[t]{5}{*}{26} & 28 & $224 \cdot 0$ & Enterobacter agglomerans & Yes \\
\hline & & 38 & $15 \cdot 9$ & Klebsiella pneumoniae & Yes \\
\hline & & 43 & 12.8 & $\begin{array}{l}\text { Escherichia coli } \\
\text { Escherichia coli }\end{array}$ & $\begin{array}{l}\text { Yes } \\
\text { Yes }\end{array}$ \\
\hline & & $\begin{array}{l}43 \\
57\end{array}$ & $\begin{array}{l}12 \cdot 8 \\
13.5\end{array}$ & Klebsiella oxytoca & Yes \\
\hline & & 57 & $13 \cdot 5$ & $\begin{array}{l}\text { Klebsiella oxytoca } \\
\text { Escherichia coli }\end{array}$ & $\begin{array}{l}\text { Yes } \\
\text { Yes }\end{array}$ \\
\hline \multirow[t]{3}{*}{4} & \multirow[t]{3}{*}{26} & 45 & $18 \cdot 9$ & Enterobacter cloacae & No \\
\hline & & 52 & $50 \cdot 2$ & Serratia marcescens & Yes \\
\hline & & 58 & $139 \cdot 3$ & Klebsiella pneumoniae & Yes \\
\hline \multirow[t]{3}{*}{5} & \multirow[t]{3}{*}{28} & 43 & $136 \cdot 1$ & Klebsiella pneumoniae & Yes \\
\hline & & & & Enterobacter cloacae & Yes \\
\hline & & 51 & $11 \cdot 3$ & Klebsiella pneumoniae & Yes \\
\hline
\end{tabular}

had started oral feeds with small amounts of expressed breast milk (1 $\mathrm{ml} /$ hour $)$ within the preceding 24 hours. Some babies were being fed with formula feeds when the metabolites were found, but most immature babies were receiving expressed breast milk. Excretion of detectable amounts of 2,3-butanediol by three babies ceased when oral feeds were discontinued and parenteral nutrition and treatment with broad spectrum antibiotics was instituted.

Generally the urinary abnormality was first observed some days after discontinuing antibiotic treatment (three to 34 days, median $12, \mathrm{n}=16$ ) (figs 1 and 2). Two babies receiving parenteral nutrition, however, were receiving gentamicin and flucloxacillin.

Fifteen rectal swabs were taken for microbiological studies from seven babies within 48 hours of collecting urine for organic acid studies. Three of the babies excreted 2,3-butanediol on nine occasions (table 4). On eight of these enterobacter, klebsiella, or serratia were identified in faecal cultures. Enterobacter cloacae was also cultured from two of six samples collected from the four remaining babies, who did not excrete the diol, but klebsiella and serratia were not isolated. Yeast organisms were grown from the groins of one baby at the time of study and there was perianal soreness, but no rectal swabs were examined in this case. No other baby was recorded as being colonised with yeast or fungi at the time of excretion of 2,3-butanediol.

\section{Discussion}

In this study, metabolites of carbohydrate fermentation produced by gut micro-organisms were found in the urine of preterm babies in a neonatal unit. The urinary abnormalities occurred particularly among VLBW babies born before 33 weeks' gestation. They excreted 2,3-butanediol more often and in higher concentrations than babies of 33 to 36 weeks' gestation. Acetoin, methylmalonic acid, and appreciable amounts of D-lactic acid were detected only in this group. The abnormalities occurred as transient episodes, always after introducing oral feeding. In three cases excretion ceased when oral feeds were withdrawn and antibiotic treatment started.

Facultative anaerobes (enterobacteriaceae) were almost certainly the sources of 2,3-butanediol and acetoin. ${ }^{115}$ These can be subdivided into organisms that produce these compounds as their main carbohydrate fermentation products (species of the genera klebsiella, enterobacter, and serratia) and those that do not (for example Escherichia coli). Acetoin is an intermediate in the fermentation pathway and is the metabolic precursor of 2,3butanediol. ${ }^{13}$ On eight of nine occasions when three babies excreted 2,3-butanediol, bacteria of the species klebsiella, enterobacter, or serratia were cultured from rectal swabs and may be assumed to have been the source of the urinary metabolite. The case for $E$ cloacae is weakened by the observation that this organism was also grown from swabs from two babies who did not excrete the diol. Small numbers of these organisms in the gut, colonic conditions unfavourable for diol production (for example, $\mathrm{pH}$ above $6 \cdot 0^{1}$ ), or decreased intestinal absorption of the metabolite, however, might all be offered as explanations for the absence of the diol in these two babies. Yeasts also produce acetoin, ${ }^{13}$ and may have accounted for 2,3-butanediol excretion in one baby, although we do not know definitely whether she had simultaneous gut and skin colonisation with these organisms.

Lactobacilli may have been the source of D-lactic acid as in older subjects following bowel resection. ${ }^{89}$ Other organisms, however, including $E$ coli, pseudomonas, and Klebsiella pneumoniae, some- 
times produce D-lactic acid as metabolic intermediate, and might have been responsible. ${ }^{1}$ Methylmalonic acid was excreted by one baby who did not have an inborn error of metabolism, and in whom vitamin $\mathrm{B}_{12}$ deficiency was an unlikely explanation in view of earlier intravenous supplementation with $0.2 \mu \mathrm{g}$ per $\mathrm{kg}$ of vitamin $\mathrm{B}_{12}$ daily. Methylmalonic acid is produced by anaerobes such as the bacteroidaceae (including Bacteroides fragilis) as an intermediate in glucose fermentation. ${ }^{115}$ Butyric acid-an end product of the pathway-may have been the precursor of ethylmalonic acid, which was also detected in this baby's urine.

To our knowledge acetoin has not been found in urine before, and the other carbohydrate fermentation products found have been encountered only rarely in older subjects. What is it that makes premature babies unique? Firstly, they have increased intestinal permeability compared with babies born at full term, and the bacterial metabolites were probably well absorbed. This is particularly likely among the immature babies, and probably helps to explain why they excreted the metabolites more often than babies born after 33 weeks' gestation. The key feature, however, is probably that preterm infants have markedly impaired intestinal absorption of lactose. ${ }^{56}$ This reflects the late development of intestinal lactase which, at 26 to 34 weeks' gestation, is only $30 \%$ of the activity at full term. ${ }^{16}$ The colonic bacteria are therefore exposed to large amounts of unabsorbed sugar that they can use as metabolic substrate. This is in some ways analogous to older subjects after ileal resection. The ready supply of carbohydrate may favour growth of enterobacteriaceae and would thereby underly another important feature of prematurity-namely, the high ratio of facultative anaerobes to strict anaerobes among the colonic microflora compared with babies born at full term, ${ }^{17}$ which persists for several weeks. ${ }^{18}$ Colonisation with enterobacter and klebsiella may occur often among babies on neonatal intensive care units, ${ }^{19}$ and is favoured by antibiotic regimens in common use. Overgrowth with klebsiella was reported during treatment with five different combinations of systemically administered antibiotics, ${ }^{17}$ and high counts of klebsiella and enterobacter reported after treatment. ${ }^{1720}$ Development of antibiotic resistance, common among these bacteria, ${ }^{21}$ would be a further factor in promoting their growth. Most babies in this study had received broad spectrum antibiotics before the appearance of 2,3-butanediol in their urine.

The findings support evidence from breath hydrogen analysis of bacterial carbohydrate fermentation in the gut of preterm infants. ${ }^{5}$ By identifying a biochemical marker for enterobacter, klebsiella, and serratia, it has been possible to recognise episodes in which colonisation with these opportunistic, potential pathogens, ${ }^{22}$ probably occurred. Carefully combined microbiological and biochemical studies may increase our understanding of the peculiarities of the gut ecology in preterm babies, which must be a factor in their predisposition to develop necrotising enterocolitis. It has been proposed that administration of lactobacilli may be beneficial for certain newborn infants. ${ }^{23}$ The possible production of carbohydrate fermentation products that might have toxic effects ${ }^{89}$ as a result of such intervention requires more detailed investigation.

The study was supported by Children Nationwide and the mass spectrometer bought from a grant from the Wellcome Trust.

\section{References}

1 Gottschalk G. Bacterial metabolism. 2nd ed. New York: Springer-Verlag, 1986.

2 McNeil NI, Cummings JH, James WPT. Short chain fatty acid absorption by the human large intestine. Gat 1978;19:819-22.

3 Bain MD, Borriello SP, Tracey BM, et al. Contribution of gut bacterial metabolism to human metabolic disease. Lancet 1988;i:1078-9.

4 Walter JH, Leonard JV, Thompson GN, Halliday D, Bartlett K. Gut bacterial metabolism. Lancet 1988;ii:226.

5 MacLean WC, Fink BB. Lactose malabsorption by premature infants: magnitude and clinical significance. J Pediatr 1980;97: 383-8.

6 Johnson JD. Antibiotics and carbohydrate malabsorption in newborns. Am J Dis Child 1986;140:101-2.

7 Garcia J, Smith FR, Cucinell SA. Urinary D-lactate excretion in infants with necrotizing enterocolitis. J Pediatr 1984;104:268-70.

8 Oh MS, Phelps KR, Traube M, et al. D-lactic acidosis in a man with the short-bowel syndrome. N Engl J Med 1979;301:249-52.

9 Haan E, Brown G, Bankier A, et al. Severe illness caused by the products of bacterial metabolism in a child with a short gut. Eur J Pediatr 1985;144:63-5.

10 Flannery D, Lafer CZ, Roesel RA. Gut bacterial metabolism. Lancet 1988;ii:225-6.

1 Hommes FA, Bruins AP, Dajani-Wielaard J, Baarsma R. 2,3Dihydroxybutane: an unusual compound found in the gas chromatographic analysis of volatile compounds of urine. J Clin Chem Clin Biochem 1979;17:97-9.

12 Francis D. Nutrition for children. Oxford: Blackwell, 1986:30-1.

13 Mills GA, Walker V. Urinary excretion of 2,3-butanediol and acetoin by babies on a special care unit. Clin Chim Acta 1989;179:51-60.

14 Gawhen K, Bergmeyer HU. D-(-)-lactate. In: Bergmeyer HU, ed. Methods of enzymatic analysis. Vol 3. New York: Academic Press, 1974:1492-3.

15 MacFaddin JF. Biochemical tests for identification of medical bacteria. 2nd ed. Baltimore: Williams and Wilkins, 1980.

16 Antonowicz I, Lebenthal E. Developmental pattern of small intestinal enterokinase and disaccharidase activities in the human fetus. Gastroenterology 1977;72:1299-303.

17 Bennet R, Eriksson M, Nord CE, Zetterstrom R. Fecal bacterial microflora of newborn infants during intensive care management and treatment with five antibiotic regimens. Pediatr Infect Dis 1986;5:533-9.

18 Sakata H, Yoshioka H, Fujita K. Development of the intestinal flora in very low birth weight infants compared to normal fullterm newborns. Eur J Pediatr 1985;144:186-90. 
${ }^{19}$ Goldmann DA, Leclair J, Macone A. Bacterial colonization of neonates admitted to an intensive care environment. $J$ Pediatr 1978;93:288-93.

${ }^{20}$ Bennet R, Nord CE. Development of the faecal anaerobic microflora after caesarean section and treatment with antibiotics in newborn infants. Infection 1987;15:332-6.

21 Borderon JC, Gold F, Laugier J. Enterobacteria of the neonate. Biol Neonate 1981;39:1-7.

22 Clark DA, Thompson JE, Weiner LB, et al. Necrotizing enterocolitis: intraluminal biochemistry in human neonates and a rabbit model. Pediatr Res 1985;19:919-21.
${ }^{23}$ Goldmann DA. The bacterial flora of neonates in intensive care-monitoring and manipulation. J Hosp Infect 1981;11 (suppl A):340-51.

Correspondence to Dr V Walker, Clinical Biochemistry, Level D, South Block, Southampton General Hospital, Southampton SO9 $4 X Y$.

Accepted 8 May 1989 